\title{
Econometric Modeling of the Bank's Short-Term Liquidity Dynamics Based on Multi-Factor Regression
}

\author{
E. G. Shershneval $\mathbb{D}^{\square}$, H. B. Bakr Hasan ${ }^{1} \mathbb{D}$, J. Al Hadabi ${ }^{2} \mathbb{1}$ \\ ${ }^{1}$ Ural Federal University named after the first President of Russia B. N. Yeltsin, \\ Ekaterinburg, Russia \\ ${ }^{2}$ Murdoch University, Dubai, \\ United Arab Emirates \\ \elena_sher@el.ru
}

\begin{abstract}
The article develops theoretical and methodological aspects of the predicative analysis of liquidity in the banking sector in the context of diversity and divergence of factors affecting the liquidity position of modern banks. The aim of the work is to study the dependence of short-term liquidity of a bank on a number of economic indicators based on econometric modeling. We used a systematic analytical approach to the study of liquidity formation factors and methods of comparative data analysis. The key methodological instrument of the empirical part of the study is multivariate correlation and regression analysis based on the parametric choice of performance indicators of a large bank in the Ural region. This study did not confirm the dominant thesis about the negative impact of excess liquidity on the profitability of commercial banks. Thus, a comparative analysis of the liquidity ratio and return on assets of Russian banks of various sizes for the period 2015-2019 did not reveal the existence of an explicit inverse-proportional relationship between liquidity and profitability. The analysis of pair correlations also did not reveal a close relationship between the value of current liquidity ratio and the bank's operating profit. The authors noted that small-sized banks are able to demonstrate a combination of high liquidity and high profitability, while larger banks may not achieve such results. Consequently, the scale of the bank's activities is not the determining factor in liquidity but indirectly provides quick access to funding sources. The authors have constructed regression models of the dependence of the mandatory current liquidity ratio of a bank on a number of performance indicators, making it possible to carry out a forecast-analytical assessment of liquidity for the short term outlook. It is established that own capital, short-term liabilities and overdue loan debt have a significant impact on the dynamics of the bank's liquidity. The proposed approach can be applied by analytical departments of commercial banks in the development of predicative models for the monitoring the liquid position.
\end{abstract}

Key words: commercial bank; banking sector; liquidity; liquidity factors; unbalanced liquidity risk; current liquidity ratio; liquidity management; capital; short-term liabilities; liquid assets.

JEL C33, C54

\section{Research relevance and problematics}

Regulation of liquidity is an important sphere of bank management. Strategic aspects are the setting of liquidity targets and the choice of appropriate instruments and methods to achieve them. A tactical direction is the setting of a system of analysis and monitoring of the bank's liquidity indicators and the determining factors. A commercial bank is considered liquid if it has sufficient funds to meet its obligations in full. However, there are plenty of factors and conditions disrupting normal 
financial performance and cause a status of unbalanced liquidity.

The unbalance of the bank's liquidity position (lack or excess) is one of the key problems of financial management. Lack of liquidity worsens solvency and excess reduces profitability. The decline of a bank's solvency is transmitted to other sectors of the economy: enterprises and individuals cannot receive money or make payments. Therefore, there are failures in the sphere of production and monetary circulation.

The specific nature of the reputation of credit institutions is found in the system of relations with customers. Loss of customer confidence inevitably leads to liquidity problems, and, conversely, liquidity problems have a negative impact on business reputation. In this context, the coherence of assets and liabilities by amounts and terms ensures the trustworthiness and stability of a bank's activity. In conditions of financial and economic instability in particular, bankers and researchers pay attention to the consequences of liquidity risk.

The matter of information and analytical support of management decision-making, which provides regulation of cash flows of a commercial bank, is actualized. The forecasting of liquidity dynamics on the shortterm horizon is important because it makes it possible to stabilize the current functioning of bank's financial mechanism.

The aim of this article is to study the econometric dependence of short-term liquidity of a commercial bank on some financial indicators (liquidity factors) based on the modeling of correlation and regression equations that allow predicting the dynamics of the mandatory current liquidity ratio.

The first task is to analyze theoretical aspects of liquidity as a complex characteristic of activity and to examine factors influencing the liquidity position of modern banks. The second task is to survey the liquidity dynamics of some Russian banks and to identify the relationship with profitability. The third point is to select relevant indicators of a commercial bank (independent variables) and to identify adequate relationships between the analyzed parameters using the method of pair correlations. The fourth task is to construct correlation and regression models (two-factor equations) that reflect an econometric dependence of the current liquidity ratio of bank (function) on the selected indicators (factors). The authors' results and conclusions formulated within the framework of the above tasks determined the originality and scientific novelty of the research.

Based on the results of other researchers and own summary, the authors concluded that the main difficulty of liquidity forecasting is the presence of many influencing factors, including controversial and unexpected. In modern conditions, when artificial intelligence elements and robotic services are being introduced in banks, the issue of developing liquidity management programs becomes urgent.

\section{Theoretical review of scientific understanding of bank's liquidity and its influencing factors}

The term «liquidity» appeared in fundamental economic studies in the 1970s. The classic author of the theory of money J. M. Keynes argued: «... liquidity is determined by the individual's preference to retain a certain amount of their resources or wages in the form of money» [1]. He offered the definition of «liquidity propensity», in which market entities have a different degree of desire to create high liquid assets to cover possible contingencies. The merit of Keynes was that he discovered and characterized the determination of the psychology of entrepreneurial behavior in a dynamic market.

D. Fisher was first, who described a more systematic understanding of liquidity in banking. According to him, the bank's liquidity is a multidimensional characteristic 
of the activity, reflecting the quality of bank's resources (own and borrowed), the quality of assets (loans, investments, securities), as well as the quality of the bank's management [2]. The identical point of view is presented in the monograph by J. Rivoir, which treats the bank's liquidity as a complex indicator reflecting the assets, liabilities and off-balance sheet transactions, as well as the level of their management [3]. The review of scientific views of a number of authors on liquidity has identified three main approaches to understanding liquidity (Fig. 1).

The basic scientific concept of liquidity in banking is an ability to ensure the timely and full performance of obligations to depositors, creditors and other counterparties. According to financial intermediation theory, $« \ldots$ the creation of liquidity is a key reason why banks exist» [4]. In the opinion of M. Gertler and N. Kiyutaki, banks create liquidity on the balance by financing relatively illiquid assets such as business loans with relatively liquid liabilities such as transactions deposits [5]. Liquidity compression occurs when there are nonpayments on loans and other claims, as well as in the case of withdrawal of deposits [6]. Many researchers emphasized that the fundamental role of banks as «creators of liquidity» makes them sensitive to liquidity risk (or unbalanced liquidity risk). As a rule, the main task of the bank's financial management is to achieve a balanced (normal) liquidity.

The imbalance leads either to a lack of liquidity or to an excess of liquidity. The lack of liquidity «constrains» the banking system, increases the risks of loss of solvency of banks, as well as reduces the profitability of banking operations. In such situation, credit institutions are forced to ensure solvency to maintain excess volumes of liquid and low-income assets. Excessive liquidity of banks means their inability to effectively dispose resources. As a rule, banks keep paid liabilities on low-yield deposits in the Central Bank, which means a negative bank margin and the fact of «eating» of capital [7]. In the study of V. Acharya and H. Naqvi [8] noted the negative impact of excess liquidity on the economy. The authors argue that banks creating a lot of liquidity can pursue credit policies that generate «asset price bubbles» and increase the fragility of the banking sector. The importance of bank liquidity creation is heightened during financial crises. For example, in the subprime lending crisis, liquidity seemed to dry up for an extended time, with severe consequences for the real sector.

Modern researchers, studying theoretical foundations of liquidity management

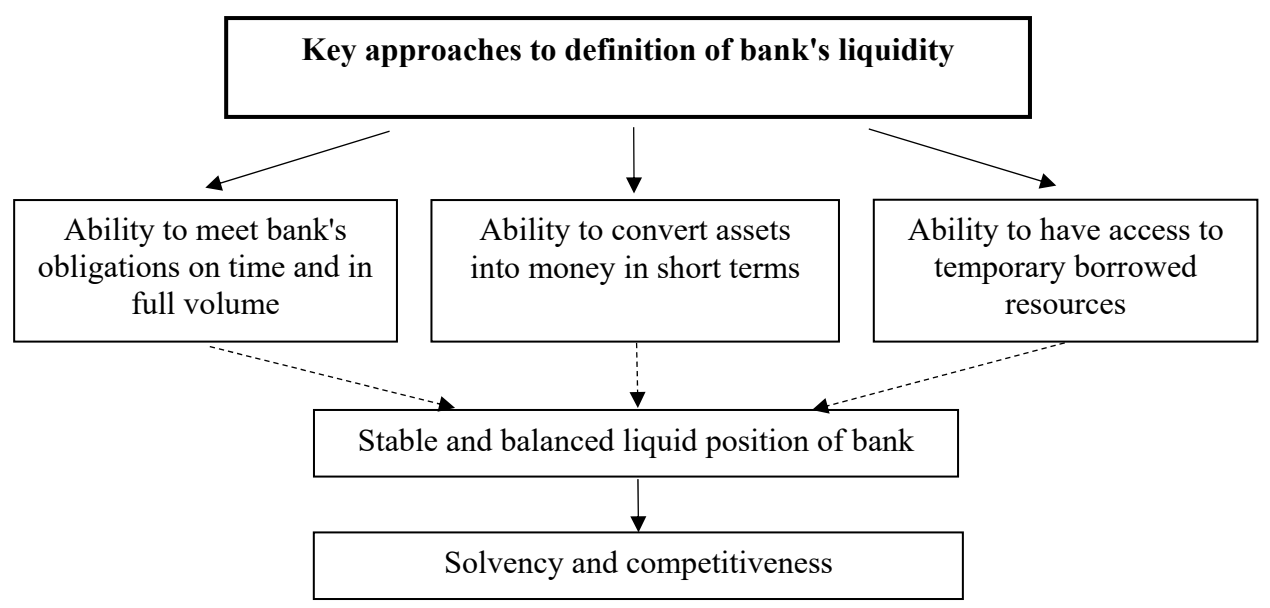

Fig. 1. Essence of liquidity in banking 
in the banking sector, based on the provisions of predecessors, developing causal relationships between liquidity factors and financial performance of commercial banks. Thus, Russian scientists V.K. Burlachkov, M. Yu. Golovnin, A. O. Tikhonov concluded that: first, liquidity is considered as a feature of the financial system or economic entity; second, it is measured by a set of variable indicators; third, it is characterized by dynamism (ability to increase and decrease) [9]. It is obvious that this understanding of liquidity in the papers of modern authors differs from its earlier interpretation actually as a synonym of money.

The bank's liquidity is determined by external and internal factors. As a rule, the dominant part of liquidity problems arises due to the influence of external factors outside the area of responsibility of bank's managers. Negative external factors can be considered the deterioration of the political and economic situation, unfair actions of competitors, withdrawal of depositors of their money. Adverse factors also include growing inflation, the decline in population's propensity to save, the emergence of «financial bubbles» in the securities market, the compression of the interbank market, the introduction of foreign sanctions against the banking sector, industry crises, tightening of regulatory measures and others.

The results of analysis of the relationship of various external factors and liquidity of banks, as well as the development of econometric models of scenario liquidity forecasting are reflected in the works of a number of foreign scientists. Researcher Jan Willem van den End [10] considered an interbank lending market as a source and the main channel of transmission of liquidity risk and strengthening of «shocks of unbalanced liquidity». In studies of T. Adrian and H.S. Shin [11], C.A.E. Goodhart, P. Sunirand and D. P. Tsomocos [12] presented the models of interbank contagion of liquidity risk. In their opinion, the «channel of infection» acts when banks lose liquidity due to the non-payment by other banks of interbank loans or deposits. Contagion can also take the form of closing deposits and withdrawing money from correspondent accounts for fear that banks will not be able to meet their obligations due to losses incurred on interbank risks. After analyzing these works, we consider that the main disadvantage of such «domino models», characterizing the transfer of unfavorable impulses in the interbank market is that they do not take into account changes in interest rates.

Monetary policy instruments have an impact on the liquidity of the banking sector. This happens through the transmission mechanism. In a study about the impact of deposit rates on liquidity, author V. Dinger examined emerging economies for the period of 1994 to 2004 and found that increasing of deposit rate decreases bank liquidity [13]. The article [14] investigated the influence of mandatory reserves as a measure of regulatory burden and showed that the tightening of reserve requirements for banks leads the reduction of liquidity and investment opportunities of banks. As a result, the probability of extinction of some medium-sized and small regional banks increases, which worsens the competitive conditions in the banking market.

In addition, the development of information technologies and payment systems has an impact on banking. Ledrut in his paper [15] carried out an analysis of payment systems as potential sources of liquidity shocks and concluded the existence of influence of technical risks on the occurrence of liquidity risk.

In some studies, it is noted that one of the important external factors is the behavior of the bank's customers. This is particularly noticeable in emerging markets. For example, customer sentiment affects liquidity in Indian banks. Authors B. Eichengreen 
and P. Gupta [16] identified panic behavior of depositors as one of the main causes of liquidity problems. For example, in Russia there were many cases when customers undermined the liquidity of banks. In the wake of information about the revocation of a bank license, investors and depositors massively withdrew their savings. In such a situation, banks had an outflow of money and liquidity risk.

Considering internal factors of bank's liquidity, appears a wide range of internal banking processes that determine the quality of management system of banks as a whole, as well as the effectiveness of management decisions in certain areas of activity. High quality of assets and stability of deposits are the key conditions of a balanced liquid position of banks. Sustainable liquidity creates a competitive advantage.

For analysis of influence of internal factors on liquidity, scientists use different economic indicators of bank activity. Thus, researchers D. V. Diamond and R. G. Rajan [17] mathematically proved that the reduction of pool of liquid assets, the increase in demand liabilities and panic behavior of depositors lead to a liquidity deficit. They also argued that greater capital buffer led to less liquidity. In opposition, an article by A. N. Berger and C. H. Bouwman [18] has detected that availability of high capital increases bank's risk absorbing capacity. Horvath et al. [19] studied the relationship between capital and banks liquidity and found that small banks with a high level of capital adequacy demonstrated less liquidity whereas large banks with middle capital adequacy characterized by high liquidity. Other authors have noted that bank size is a significant parameter that affects bank liquidity [20, 21, 22]. They found an inverse relationship between bank size and liquidity. This finding suggests that large banks are more liquidly and less exposed to the risk of unbalanced liquidity.
Liquidity is inversely proportional to the bank's profitability and «risk appetite»: high liquidity indicators prevent higher profitability, and conversely, the desire to increase profitability by investing in risky and profitable assets can lead to liquidity deficit. The most rational bank's policy in the field of liquidity management is to ensure an optimal combination of liquidity, profitability and risk level. This condition is usually achieved through careful targeting, proper financial planning and reasonable risk appetite. Scientists A. Singh and A. K. Sharma proved the hypothesis: increase in profitability decreases bank liquidity. They explained: «...profitability of banks shows the ability of banks to generate income out of assets. Banks with high profitability tend to involve in risky strategies that may cause liquidity problems» [23]. Herewith, Aspachs et al. [24] concluded that profitability showed a slight relationship with liquidity. In some studies revealed, that growth of profitability has a positive effect on the bank's liquidity $[25,26]$.

Banks are dependent on deposits and external funds for their liquidity needs. The volume and structure of deposits have a significant impact on bank liquidity [23]. Than more stable deposits, then more sustainable bank's liquid position. In the event of the rising of short-term liabilities, the probability of liquidity risk increases.

Another endogenous factor is the overdue debt on loans (non-performing loansNPL). When the NPL increases, the incoming cash flow decreases. In case of emergence or growth of NPL, there is a need of formation of loan provisions (reserve). In fact, NPL is non-profitable assets («lazy money») and reserves are bank's expenses («risk pillow»). If the reserve is formed for more than previously planned value, the level of bank's capital will decrease, and this will have a negative impact on liquidity. 
Therefore, exploration of external and internal factors affecting liquidity is an important tactical management instrument, as it allows forecasting and preventing possible deterioration of financial standing. Thus, the most significant analytical objects in assessing the bank's liquidity are assets, liabilities, capital, profitability and specific bank risks. To quantify a bank's liquidity, almost all countries have introduced mandatory liquidity ratios and assessment methodologies. Aware of the need to improve bank management and control of liquidity, the Basel Committee on Banking Supervisor issued in 2008 the principles for Sound Liquidity Risk Management and Supervision. These principles set out the key elements of a reliable system of liquidity risk management in banking institutions, which correspond to the views of banking supervision.

In Russian practice, analytical and methodological document of the liquidity's analysis is the Bank of Russia's Instruction № 4336-U dated 03.04.2017 «On the assessment of the economic situation of banks», in which liquidity is diagnosed on a group of indicators:

1. Total short-term liquidity ratio;

2. Instant liquidity ratio (the mandatory standard $\mathrm{H} 2$ );

3. Current liquidity ratio (the mandatory standard $\mathrm{H} 3$ ); funds;

4. Indicator of structure of borrowed

5. Indicator of depending on interbank market;

6. Risk-coefficient of own promissory note liabilities;

7. Volume of mandatory reserves;

8. Risk-coefficient for major creditors and depositors;

9. Indicator of claims not fulfilled by bank to creditors.

The summary result is the average weighted value of all the above indicators based on the score and weight. At the same time, the greatest weight is assigned to the indicators of instant and current liquidity. That is, from the position of the Bank of Russia, the most significant indicators of a bank's liquidity are mandatory ratios of instant and current liquidity.

Management of instant (one-day) liquidity is reduced to monitoring of daily incoming and outgoing cash flows and maintaining the necessary stock of highly liquid assets (cash and correspondent account, as well as in the mandatory reserves account). Current liquidity reflects the bank's cash flow for up to 30 calendar days and, accordingly, is an indicator of solvency in the future.

An important direction of banking management is to set up an information and analytical system of liquidity maneuver, which provides employees with the necessary relevant data and methods of processing to obtain information in the field of decision-making. Relevant analysis of liquidity factors, forecasting and modeling of liquidity position are particularly important in periods of increasing inflation risks and imbalance of macroeconomic processes. For this purpose, the appropriate mathematical methods of econometric modeling are used.

\section{Econometric modeling of relationship between bank's current liquidity ratio and economic indicators}

This research part is devoted to the analysis of liquidity on the example of Russian banks and consists of two stages.

First stage. Analysis of the dynamics of the current liquidity ratio on the example of several banks with different asset sizes. The goal is to determine the situation of liquidity in the banking sector and detect trends.

As mentioned above, the key indicators of a bank's liquidity are instant and current liquidity ratios. Since the instantaneous 
liquidity ratio (H2) has not predictive significance and reflects the liquid position only on the reporting date, this indicator will not be used in further analysis. We have chosen the current liquidity ratio (H3) as the object of analysis. Based on official statements of the analyzed banks, we made a chart (Fig. 2) showing the dynamics of the H3.

Fig. 2 shows a trend of the increase in liquidity ratio since 2017 . This is especially evident on the chart of SBERBANK. In all banks, regardless of their size, the current liquidity ratio exceeds the minimum value several times in 2019. This indicates that the analyzed banks have sufficient liquidity. This correlates with reports of the Bank of Russia about a liquidity surplus in the Russian banking sector.

Next, consider the change in the return on assets (ROA) for the same period (Fig. 3). This relative indicator allows you to compare the performance of different banks and evaluate their effectiveness. The increase in profitability is noted at the beginning of each year. This is due to the increase in interest income, as this

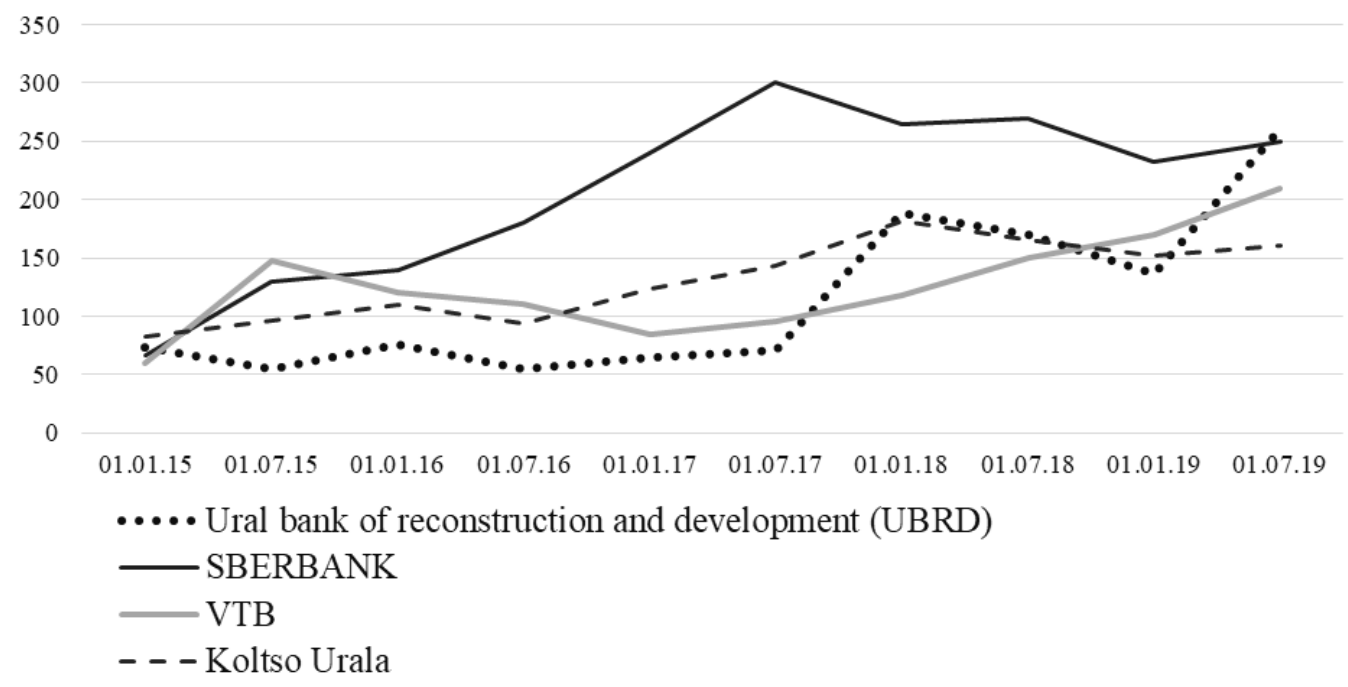

Fig. 2. Dynamics of current liquidity ratio (H3) of some Russian banks, \%

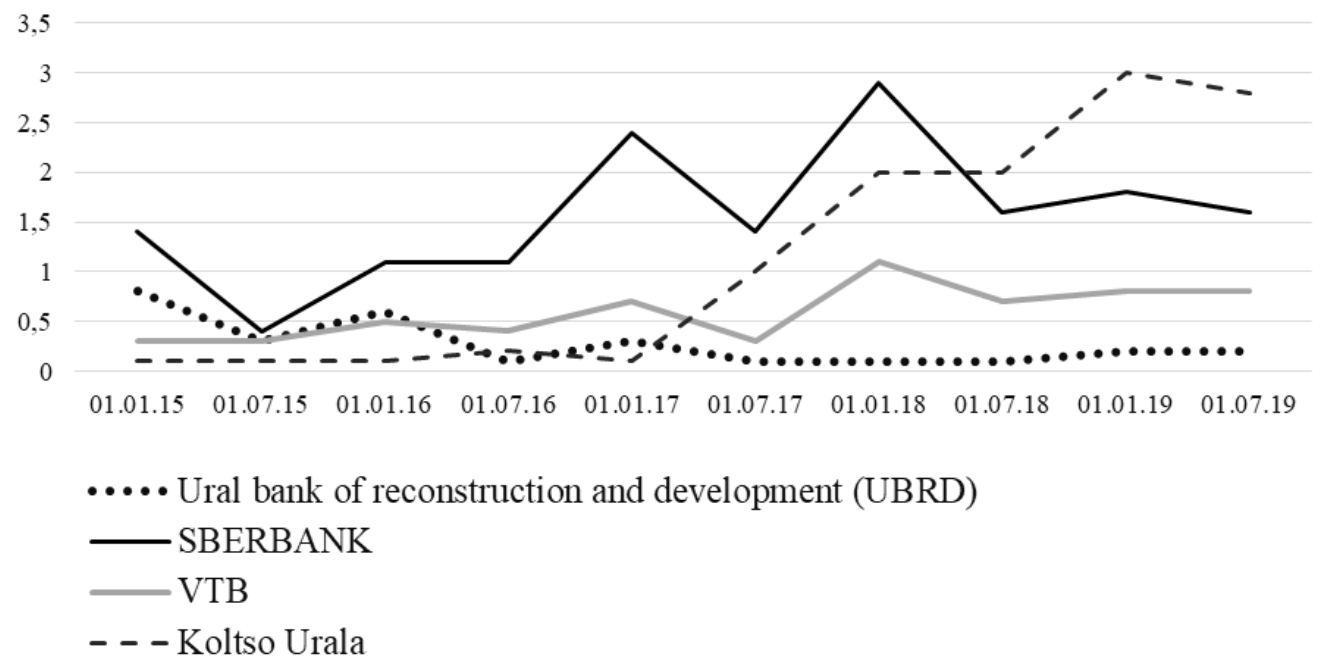

Fig. 3. ROA dynamics of analyzed banks, \% 
is when large payments on loans and securities occur.

In 2019, the highest ROA was at thesmall-sized bank Koltso Urala. Its current liquidity ratio decreased, that is, the bank invested in profitable assets. SBERBANK has the same dependency: liquidity downprofitability up. Bank VTB liquidity growth is accompanied by a slight increase in profitability. UBRD has a significant increase in liquidity and lack of profitability dynamics.

In the summary we have not identified a clear and unambiguous relation between the indicator of current liquidity and profitability. This finding correlates with the results of O. Aspachs et al. [24], P. Vodová [25], V. C. Lartey et al. [26]. We also found that small bank demonstrates high liquidity and high profitability. Larger banks did not show the same results.

Second stage. The result of the modeling of a bank's liquidity dynamics based on the correlation and regression method and parametric selection of factors affecting the medium-term liquidity position is presented below. The goal of modelling is to receive regression equations, which allow one to predict the current liquidity ratio of a bank.

For the purposes of regression analysis, we used data from one of mediumsized Russian banks (JSC «Ural bank of reconstruction and development»-UBRD) for the period 01.01.2015-01.07.2019. The choice of bank was due to its good reputation at the regional level, high credit activity, non-affiliation with government structures. This bank is characterized by financial stability and compliance with all mandatory ratios in accordance with the Instructions of the Bank of Russia № 180-I.

The object of modeling is the current liquidity ratio (H3). It can be considered as a predicative parameter for forecasting the bank's liquid position for a period of $30 \mathrm{cal}-$ endar days. This ratio is calculated by the following formula:

$$
H 3=\frac{L A(\text { short })}{O B L(\text { short })-\operatorname{Min} O B L} \times 100 \% \geq 50 \%
$$

LA (short) - liquid assets that can be received by bank, and (or) can be claimed within the next 30 calendar days;

OBL (short) - liabilities that can be claimed by depositors and (or) creditors within the next 30 calendar days;

Min $O B L$ - value of the minimum aggregate residue on demand accounts of individuals and legal entities for the period of performance of obligations in the next 30 calendar days.

The minimum permissible level of the liquidity ratio $\mathrm{H} 3$ is $50 \%$. Banks must constantly maintain a certain level of high liquid assets in accordance with this requirement in case of stressful situations, accompanied by an acute shortage of liquidity.

The actual values of this ratio of the analyzed bank for the reviewed period are significantly higher than the normative. There is a trend of gradual growth (Fig. 4). Than higher the value of this standard, then greater the liquidity reserve. It should be noted that since the beginning of 2018, the figure has increased drastically. Significant excess of this ratio indicates excessive liquidity of the bank, which is a negative factor, as excessive liquidity affects the profitability of operations negatively. In this case, the bank should pay attention to the structure of assets: it is possible to redistribute part of liquid assets with a minimum level of risk to more profitable areas of investment.

Modeling of bank's current liquidity dynamics will be carried out on the basis of the following performance indicators:

1. Current liquidity ratio $(\mathrm{H} 3)-\mathrm{Y}, \%$;

2. Operational profit-X1, billion rubles;

3. Obligations with a term of performance within 30 calendar days (short-term liabilities) - X2, billion rubles;

4. Overdue loan debt $-\mathrm{X} 3$, billion rubles;

5. Own capital - X4, billion rubles. 


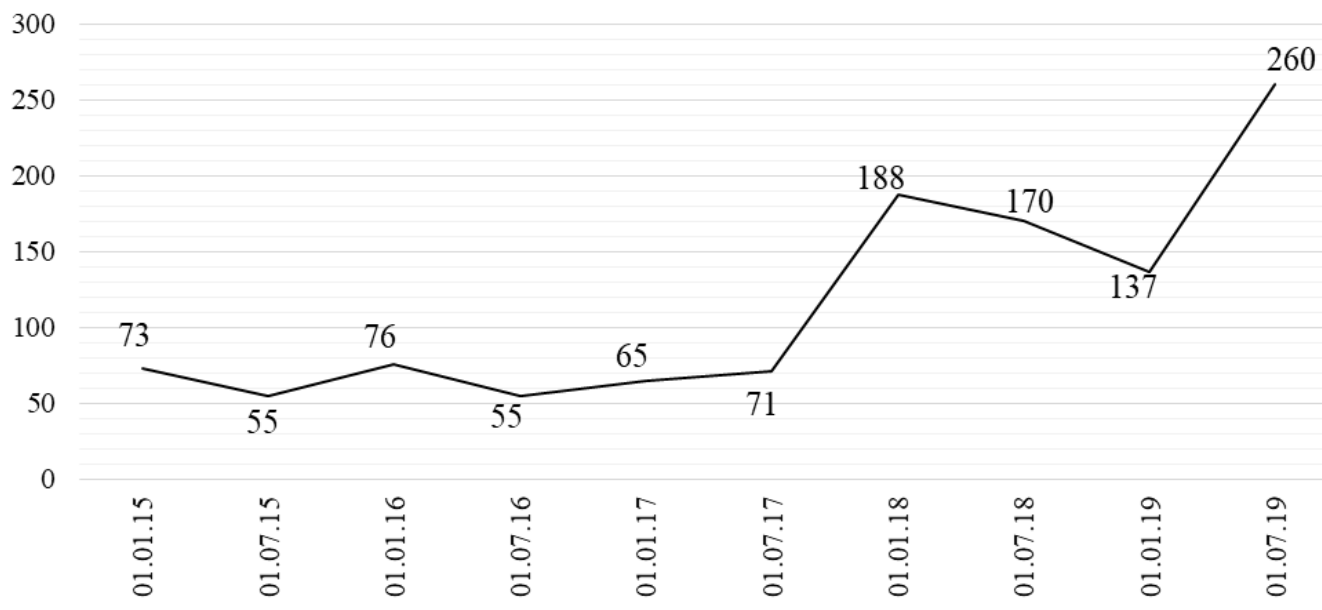

Fig. 4. Dynamics of current liquidity ratio (H3) of UBRD, \%

Table 1 presents the results of calculating of paired correlation matrix.

According to Table 1, there is a persistent direct-proportional relationship between $\mathrm{H} 3$ ratio and bank's capital (X4). There is also a significant inverse correlation between $\mathrm{H} 3$ and short-term liabilities (X2) and between H3 and overdue loans (X3).

The following relationships are observed between the factors: close feedback between profit (X1) and overdue loan debt (X3), rather strong direct relationship between short-term liabilities (X2) and the bank's capital (X4). If there is a close relationship between the factors, these factors cannot be used in the regression model. Thus, the parameters X1 and X3, as well as X2 and X4 cannot simultaneously be included in one regression model, because there is a significant correlation.
The regression models are presented in a standardized form (Table 2), which do not contain linearly dependent variables. Of these models, the most relevant ones will be selected for construction of equations in natural form (taking into account the importance of equation parameters and the determination coefficient).

The analysis of Table 2 shows that only in models 1 and 2 both regression parameters are significant. Factors X2 (short-term liabilities) and X4 (capital) have the greatest impact on variable Y. In models 3 and 4 the factor X1 is insignificant, therefore, these equations will not be used for further analytical procedures.

Subsequent calculations make it possible to create linear regression equations in natural form (Table 3).

Analysis of beta-coefficients reveals the degree of significance of each factor in

$\overline{\text { Table 1. Matrix of pair correlation coefficients }}$

\begin{tabular}{c|c|c|c|c|c}
\hline & $\mathrm{Y}$ & $\mathrm{X} 1$ & $\mathrm{X} 2$ & $\mathrm{X} 3$ & $\mathrm{X} 4$ \\
\hline $\mathrm{Y}$ & 1 & & & & \\
$\mathrm{X} 1$ & 0,361 & 1 & & & \\
$\mathrm{X} 2$ & $-0,975$ & 0,138 & 1 & & \\
$\mathrm{X} 3$ & $-0,754$ & $-0,829$ & $-0,571$ & 1 & 1 \\
$\mathrm{X} 4$ & 0,872 & 0,095 & 0,883 & $-0,478$ & 1 \\
\hline
\end{tabular}




\section{Table 2. Two-factor regression models in standardized form}

\begin{tabular}{|c|c|c|}
\hline $\begin{array}{l}\text { Regression equations } \\
\text { in standardized form }\end{array}$ & $\mathrm{R} 2$ & Comment \\
\hline $\begin{array}{l}\text { Model } 1 \\
\mathrm{~T}_{\mathrm{Y}}=-0,782 * \mathrm{~T}_{\mathrm{X} 2}-0,312 * \mathrm{~T}_{\mathrm{X} 3}\end{array}$ & 0,981 & $\begin{array}{l}\text { Both regression parameters are significant, the re- } \\
\text { gression equation as a whole is significant }(98,1 \% \text { of } \\
\text { the variation is explained by constructed equation). }\end{array}$ \\
\hline $\begin{array}{l}\text { Model } 2 \\
\mathrm{~T}_{\mathrm{Y}}=0,728 * \mathrm{~T}_{\mathrm{X} 4}-0,451 * \mathrm{~T}_{\mathrm{X} 3}\end{array}$ & 0,985 & $\begin{array}{l}\text { Both regression parameters are significant, the re- } \\
\text { gression equation as a whole is significant ( } 98,5 \% \text { of } \\
\text { the variation is explained by constructed equation). }\end{array}$ \\
\hline $\begin{array}{l}\text { Model } 3 \\
\mathrm{~T}_{\mathrm{Y}}=0,184 * \mathrm{~T}_{\mathrm{X} 1}-0,963 * \mathrm{~T}_{\mathrm{X} 2}\end{array}$ & 0,939 & $\begin{array}{l}\text { Only the second regression parameter is significant, } \\
\text { the regression equation as a whole is significant }(93,9 \% \\
\text { of the variation is explained by constructed equation). }\end{array}$ \\
\hline $\begin{array}{l}\text { Model } 4 \\
\mathrm{~T}_{\mathrm{Y}}=0,154 * \mathrm{~T}_{\mathrm{X} 1}+0,931 * \mathrm{~T}_{\mathrm{X} 4}\end{array}$ & 0,91 & $\begin{array}{l}\text { Only the second regression parameter is significant, the } \\
\text { regression equation as a whole is significant ( } 91 \% \text { of } \\
\text { the variation is explained by the constructed equation). }\end{array}$ \\
\hline
\end{tabular}

predicting the value of the variable $\mathrm{Y}$ : than greater the value of $\beta$-coefficient module, then higher the influence of this factor in regression equation. In our case, the greatest contribution to the prediction of variable $\mathrm{Y}$ is made by factor $\mathrm{X} 2$, and the smallestX3 (Table 4). Thus, if the X2-factor changes by one standard deviation, the current liquidity ratio will change to $-0,782$ of its standard deviation.
To characterize the relative strength of factor's influence on the resulting indicator $Y$, we calculated average elasticity coefficients for each factor of regression equations (Table 5). The elasticity coefficient (EXi) shows how many percent will change in the average $\mathrm{Y}$ if factor $\mathrm{Xj}$ increases by one percent.

Thus, the following dependence is observed in model 1: with the growth of factor

\section{Table 3. Two-factor regression models in standardized and natural forms}

\begin{tabular}{l|c|c}
\multicolumn{1}{c|}{$\begin{array}{c}\text { Regression equations in } \\
\text { standardized form }\end{array}$} & B-coefficients & $\begin{array}{c}\text { Regression equation in natural form } \\
\mathrm{Y}=\mathrm{a}+\mathrm{b}_{1} * \mathrm{X}_{\mathrm{i}}+\mathrm{b}_{2} * \mathrm{X}_{\mathrm{i}}\end{array}$ \\
\hline Model 1 & $\beta_{1}=-0,782$ & $\mathrm{Y}=485,76-5,28 * \mathrm{X} 2-7,24 * \mathrm{X} 3$ \\
$\mathrm{~T}_{\mathrm{Y}}=-0,782 * \mathrm{~T}_{\mathrm{X} 2}-0,312 * \mathrm{~T}_{\mathrm{X} 3}$ & $\beta_{2}=-0,312$ & \\
Model 2 & $\beta_{1}=0,728$ & $\mathrm{Y}=67,35+11,28 * \mathrm{X} 4-8,51 * \mathrm{X} 3$ \\
$\mathrm{~T}_{\mathrm{Y}}=0,728 * \mathrm{~T}_{\mathrm{X} 4}-0,451 * \mathrm{~T}_{\mathrm{X} 3}$ & $\beta_{2}=-0,451$ & \\
\hline
\end{tabular}

Table 4. Ranking the importance of model factors by ß-coefficient

\begin{tabular}{l|c|c|c}
\hline \multicolumn{1}{c|}{ Analytical indicator } & X2 & X4 & X3 \\
\hline B-coefficient & $\beta=|0,782|$ & $\beta=|0,728|$ & $\beta=|0,451|$ \\
Rank of the factor's importance & $\begin{array}{c}\text { The most } \\
\text { important }\end{array}$ & Middle important & Least significant \\
Model number & 1 & 2 & 2 \\
\hline
\end{tabular}




\section{Table 5. Elasticity of regression model factors}

\begin{tabular}{c|c|c|l}
\hline Model number & $\begin{array}{c}\text { Elasticity coefficient } \\
\text { (first factor) }\end{array}$ & $\begin{array}{c}\text { Elasticity coefficient } \\
\text { (second factor) }\end{array}$ & Comment \\
\hline Model 1 & $\mathrm{E}_{\mathrm{X} 2}=-1,542$ & $\mathrm{E}_{\mathrm{X} 3}=-0,471$ & Elasticity on two factors is noted \\
Model 2 & $\mathrm{E}_{\mathrm{X} 4}=1,634$ & $\mathrm{E}_{\mathrm{X} 3}=-0,583$ & Elasticity on two factors is noted \\
\hline
\end{tabular}

$\mathrm{X} 2$ by $1 \%$ from its average level, the current liquidity ratio will decrease by $1,542 \%$, with the growth of factor $\mathrm{X} 3$ by $1 \%$ from the average data, the current liquidity ratio will decrease by $0,471 \%$. At the same time, the influence of factor X2 (bank's obligations with a maturity of 30 calendar days) is greater than the influence of factor X3 (overdue loan debt).

In model 2, with an increase of factor $\mathrm{X} 4$ by $1 \%$ of its average level, the current liquidity ratio will rise by $1,634 \%$, with the growth of factor X 3 by $1 \%$ of the average, the current liquidity ratio will decrease by $0,583 \%$. The strength of the influence of factor X4 (capital) is higher than factor X3 (overdue loan debt).

Therefore, the highest elasticity is the result of $\mathrm{Y}$ by factor $\mathrm{X} 4$ in model 2, the least elasticity-by factor X3 in model 1 (Table 6).

Factor ranking allows for estimating the prognostic value of regression equations. Accordingly, for the purposes of forecasting the current liquidity ratio (H3) of the analyzed bank, the model 2 is the best suited. The most significant factors are capital (X4), bank's short-term obligations (X2) and overdue loan debt (X3). Significant impact of these factors is explained by the following determination. The increase in capital, which occurs through the additional issue of shares, ensures the receipt of funds to the bank's correspondent account. This supports the liquidity position. The rising in short-term liabilities characterizes the increased probability of their withdrawal, which causes the presence of liquidity risk. The growth in overdue loans leads to a reduction in bank's assets and income, which ultimately worsens liquidity.

To predict the H3 indicator, we will use hypothetical data of the factors X2, X3, $\mathrm{X}$, which differ from the actual data of the bank (differing in a big way). Substituting the values of the factors, we obtain the result of calculation (Table 7).

So, with an increase in short-term liabilities and overdue loans, there is a decrease in the forecast value of $\mathrm{H} 3$ compared

\section{Table 6 . Ranking of factors by the force of influence on the variable $Y$}

\begin{tabular}{l|c|c|c|c}
\hline \multicolumn{1}{c|}{ Analytical indicator } & $\mathrm{X} 4$ & $\mathrm{X} 2$ & $\mathrm{X} 3$ & $\mathrm{X} 3$ \\
\hline Elasticity coefficient & $\Im_{\mathrm{X} 4}=1,634$ & $\Im_{\mathrm{X} 2}=-1,542$ & $\Im_{\mathrm{X} 3}=-0,583$ & $Э_{\mathrm{X} 3}=-0,471$ \\
Model number & 2 & 1 & 2 & 1 \\
\hline
\end{tabular}

\section{Table 7. Forecasting of the current liquidity ratio (H3)}

\begin{tabular}{l|c|c}
\hline \multicolumn{1}{c|}{$\begin{array}{c}\text { Projected values of factors, } \\
\text { billion rubles }\end{array}$} & Regression equation & $\begin{array}{c}\text { Result of forecast } \\
(\mathrm{H} 3), \%\end{array}$ \\
\hline $\begin{array}{l}\text { Short-term liabilities (X2)-60 } \\
\text { Overdue loan debt (X3)-10 }\end{array}$ & $\mathrm{Y}_{\text {Model 1 }}=485,76-5,28 * \mathrm{X} 2-7,24 * \mathrm{X} 3$ & 96,56 \\
Own capital (X4) -20 & $\mathrm{Y}_{\text {Model 2 }}=67,35+11,28 * \mathrm{X} 4-8,51 * \mathrm{X} 3$ & 207,85 \\
\hline
\end{tabular}


to the average for the period under review (pessimistic scenario). If there is an increase in capital, the $\mathrm{H} 3$ ratio can acquire an increased value (optimistic scenario). In order to achieve a balanced current liquidity, indicated factors should be under the attention of bank's experts and managers.

\section{Discussion of the research results}

The theoretical review showed that the study of bank's liquidity factors is within the scope of interests of many scientists. Some analyze external factors of liquidity (J. W. Van den End, T. Adrian, H. S. Shin, C. A. E. Goodhart, P. Sunirand, D. P. Tsomocos etc.) and others focus on the study of internal determinants (D. V. Diamond, R. G. Rajan, A. N. Berger, C.H.S. Bouwman, R. Horvath, J. Seidler, L. Weill, V.C. Lartey, S. Antwi, E.K. Boadi and others). At the same time, all researchers agree that liquidity is a multidimensional characteristic, which depends on many endogenous and exogenous factors. The authors believe that liquidity is important for banks due to their high leveraged positions to compensate expected and unexpected cash outflows. It is noted that balanced liquidity characterizes the quality of bank management.

The complexity of liquidity forecasting lies in the probabilistic nature of customer behavior. It is difficult to determine exactly what will happen to liabilities and assets. So, all existing methods of estimation are based on certain assumptions and give only approximate values. Our proposed regression models reflect dependence of the current liquidity ratio (H3) on short-term liabilities, overdue loan debt and own capital. We estimated that capital and short-term liabilities are the most important liquidity factors. With the growth of capital, there is a significant increase in liquidity. This result correlates with findings of A.N. Berger and C.H.S. Bouwman [18]. They pointed out that the high level of capital helps banks to create more liquidity. As well as increasing capital will protect against risks. After the global financial crisis of 2009, the Basel Committee on Banking Supervision proposed new capital adequacy requirements for solvency and liquidity.

Short-term obligations are mobile part of a bank's liabilities. Any negative macroeconomic factors can cause an outflow of deposits, which will disrupt the liquidity balance. That is why banks develop attractive deposit conditions to retain stable liabilities.

Since 2016, the Bank of Russia has been systematically reducing the key rate, which contributed to a change in the parameters of stability of the resource base of Russian commercial banks. Because of the decline in yield on deposits, savings activity of peoples and corporate clients decreased. The dominance of short-term deposits in the composition of resources not only makes it difficult to maneuver liquidity, but also does not allow banks to finance investment projects and stimulate the development of the investment potential of the regions. Further maintaining the imbalance between short-term banking resources and the economy's needs for long-term financial investments cultivates degradation processes in the Russian economy and does not contribute to its sustainability.

In addition, it has been established that liquidity indicators have a weak relationship with profit, which is reflected in study [24]. First, this is due to peculiarities of calculation of the $\mathrm{H} 3$ ratio: it does not include profit indicators. Second, bank's profit is small parameter compared to capital, assets and liabilities.

In general, the following features characterize the Russian banking sector. Liquid resources are distributed unevenly across the banking system: the main recipients of liquidity are the largest banks. The received 
funds are directed either to the foreign exchange market or to the implementation of their own projects. The mechanism of liquidity movement from larger to smaller banks («liquidity cascade») is weak. There is a situation when state-owned banks (super liquidity) are in conditions that are more competitive. Thus, the largest banks with state participation account for about $60 \%$ of deposits of citizens, consequently regional banks have to set higher interest rates to attract public funds. As a rule, the increase of interest rates on deposits leads to a rising of interests on loans, which reduces competitiveness of medium-sized and small banks.

The emergence of factors reducing competitiveness leads to revision of strategic targets. In conditions of high transaction costs, «information asymmetry» and strict capital requirements, banks look for a new areas of business that are not associated with financial intermediation. The weakening of financial intermediation as the main function of commercial banks was called financial disintermediation. In bank sector, this is manifested in form of expansion of pension and insurance services under partner programs, the emergence of new stock instruments and banking services. The presence of these banking services can be considered a progressive direction of financial disintermediation. However, there is a negative effect: financial disintermediation can reduce the volume of lending to industrial sector of the economy.

\section{Conclusion}

Financial crises have shown that liquidity problems of commercial banks can spread not only in financial system of state, but also at the international level. The consequences of unbalanced liquidity can lead to bankruptcy. To reduce liquidity risk, banks are required to comply with mandatory liquidity ratios. For this, banks maintain a certain proportion of liquid assets and regulate assets and liabilities by terms and amounts. In order to timely maneuver cash flows, it is necessary to predict and analyze many factors and parameters of bank's activity. The difficulty is that banks cannot influence external factors affecting liquidity. Internal factors are manageable and can be adjusted. Therefore, theoretic and econometric analysis of relationship between the liquidity indicator and key financial metrics of commercial bank is defined as a subject of this study. As a result, the following theoretical and practical results are obtained.

First, the analysis of researcher's views on liquidity factors led to the conclusion about multidimensionality of liquidity as a characteristic of bank activity. It was also revealed that there is a complementarity of internal and external liquidity factors. We consider that the pluralism of opinions about liquidity factors expands the scientific understanding of features of financial mechanism in the banking sector.

Second, the survey of current liquidity of several Russian banks showed that there is a liquidity surplus. Analyzed banks have no lack of liquidity. This correlates with the Bank of Russia's statements about the presence of a structural liquidity surplus in the banking sector. The analysis did not reveal a clear and unambiguous relationship between the indicator of current liquidity and profitability.

Third, the authors presented results of correlation and regression modeling of dependence of the current liquidity ratio (H3) on some factor indicators of one commercial bank. The obtained regression equations allow one to predict the dynamics of short-term liquidity.

Fourth, this study showed that the current bank's liquidity is significantly affected by such parameters as capital, short-term liabilities and overdue loan debt. We found that the most elasticity is between the level of $\mathrm{H} 3$ and capital. If own capital will grow up, the forecast value of current liquidity ratio will greatly increase. Conversely, if 
the bank loses capital, liquidity deteriorates significantly. Other factors have less elasticity. If short-term liabilities and overdue debts increase, the predicative level of $\mathrm{H} 3$ will decrease (not great).

The results of this study are useful in the practice of commercial banks in the analysis and forecasting of the current liquidity ratio. The identified dependencies allow to control the parameters of activity and to adjust financial flows in a timely. This will ensure a more balanced relationship between assets and liabilities and prevent liquidity risk. This aspect is particularly relevant in the context of transition of most banks in the world to the requirements of Basel III.

It should be noted that the future focus of research interest would be directed towards the analysis of dynamic liquidity of commercial banks, which is a liquid position at a particular time and its forecast in the future. The rapid development of digital intelligence technologies and neuro-computing programs will give an opportunity «to design» the wishful liquidity position and algorithms for more effective management of unbalanced liquidity risk.

\section{References}

1. Keynes, J.M. (2007). The General Theory of Employment, Interest and Money. Palgrave Macmillan.

2. Fisher, D. (1971). Money and Banking. Homewook, Irwin, 418 p.

3. Rivoire, J. (1991). Les Techniques bancaires. Paris.

4. Berger, A.N., Bouwman, C.H.S. (2012). Bank Liquidity Creation, Monetary Policy, and Financial Crises. SSRN Electronic Journal, March. DOI: http://dx.doi.org/10.2139/ssrn.1952728.

5. Gertler, M., Kiyotaki, N. (2013). Banking, liquidity and bank runs in an infinite horizon economy. NBER Working Paper, No. 19129,. 43 p.

6. Kashyap, A.K., Rajan, R.G., Stein, J.C. (2002). Banks as liquidity providers: an explanation for the coexistence of lending and deposit-taking. Journal of Finance, Vol. 57, Issue 1, 33-73.

7. Logutova, S.V. (2011). Likvidnost' kommercheskikh bankov: prichiny krizisa i upravlenie riskom [Bank liquidity: Causes of the crisis and risk management]. Vestnik Novgorodskogo gosudarstvennogo universiteta [Bulletin of Novgorod State University], No. 61, 31-34. (In Russ.).

8. Acharya, V.V., Naqvi, H. (2010). The Seeds of a Crisis: A Theory of Bank Liquidity and Risk-Taking Over the Business Cycle. NYU Working Paper, No. 2451/29886, 60 p.

9. Burlachkov, V.K., Golovnin, M. Iu., Tikhonov, A.O. (2017). Globalnaia denezhnaia likvidnost: teoreticheskie osnovy, pokazateli, tendentsii dinamiki [Global cash liquidity: Theoretical framework, indicators, trends]. Dengi i kredit (Russian Journal of Money and Finance), No. 12, 3-8. (In Russ.).

10. Van den End, J.W. (2010). Liquidity stress-tester: a model for stress-testing banks liquidity risk. CESifo Economic Studies, Vol. 56, Issue 1, 38-69.

11. Adrian, T., Shin, H.S. (2008). Liquidity and financial contagion, in Banque de France. Financial Stability Review-Special Issue on Liquidity, Issue. 11, 1-7.

12. Goodhart, C.A.E., Sunirand, P., Tsomocos, D.P. (2006). A model to analyze financial fragility. Economic Theory, Vol. 27, Issue 1, 107-142.

13. Dinger, V. (2009). Do foreign-owned banks affect banking system liquidity risk? Journal of Comparative Economics, Vol. 37, Issue 4, 647-657.

14. Shershneva, E.G., Kondiukova, E.S., Poliakova, A.V. (2017). Vliianie rezervnykh trebovanii Banka Rossii na sostoianie bankovskoi likvidnosti i denezhnoi massy (The impact of Bank of Russia reserve requirements on bank liquidity and money supply). Finansy $i$ kredit (Finance and Credit), Vol. 23, No. 27 (747), 1597-1613. (In Russ.).

15. Ledrut, E. (2007). Simulating retaliation in payment systems: can banks control their exposure to a failing participant? DNB Working Paper, No. 133, Netherlands Central Bank, Research Department. 
16. Eichengreen, B., Gupta, P. (2013). The financial crisis and Indian banks: survival of the fittest? Journal of International Money and Finance, Vol. 39, 138-152.

17. Diamond, D.W., Rajan, R.G. (2005). Liquidity shortages and banking crises. Journal of Finance, American Finance Association, Vol. 60, Issue 2, 615-647.

18. Berger, A.N., Bouwman, C.H.S. (2009). Bank liquidity creation. Review of Financial Studies, Vol. 22, 3779-3837.

19. Horvath, R., Seidler, J., Weill, L. (2014). Bank capital and liquidity creation: granger-causality evidence. Journal of Financial Services Research, Vol. 45, Issue 3, 341-361.

20. Bonfim, D., Kim, M. (2012). Liquidity risk in banking: is there herding? // European. Banking Center Discussion Paper, No. 2012-024. DOI: https://doi.org/10.2139/ssrn.2163547.

21. Bonner, C., Van Lelyveld, I., Zymek, R. (2015). Bank liquidity buffers and the role of liquidity regulation. Journal of Financial Services Research, Vol. 48, Issue 3, 215-234.

22. Moussa, M.A.B. (2015). The determinants of bank liquidity: case of Tunisia. International Journal of Economics and Financial Issues, Vol. 5, Issue 1, 249-259.

23. Singh, A., Sharma, A.K. (2016). An empirical analysis of macroeconomic and bank-specific factors affecting liquidity of Indian banks. Future Business Journal, Vol. 2, 40-53.

24. Aspachs, O., Nier, E., Tiesset, M. (2005). Liquidity, banking regulation and the macroeconomy. Evidence on bank liquidity holdings from a panel of UK-resident banks. Bank of England Working Paper, $26 \mathrm{p}$.

25. Vodová, P. (2013). Determinants of commercial bank liquidity in Hungary. Finansowy Kwartalnik Internetowy e-Finanse, Vol. 9, Issue 4, 64-71.

26. Lartey, V.C., Antwi, S., Boadi, E.K. (2013). The relationship between liquidity and profitability of listed banks in Ghana. International Journal of Business and Social Science, Vol. 4, Issue 3, 48-56.

\section{INFORMATION ABOUT AUTHORS}

\section{Shershneva Elena Gennadyevna}

Candidate of Economic Sciences, Associate Professor, Department of Banking and Investment Management, Ural Federal University named after the first President of Russia B. N. Yeltsin, Ekaterinburg, Russia (620002, Ekaterinburg, Mira street, 19); ORCID 0000-0002-6739-8960; e-mail: elena_sher@el.ru.

\section{Hasan Barham Bakr Hasan}

Master Student, Department of Banking and Investment Management, Ural Federal University named after the first President of Russia B. N. Yeltsin, Ekaterinburg, Russia (620002, Ekaterinburg, Mira street, 19); ORCID 0000-0002-5239-4537; e-mail: barhambakr@gmail.com.

\section{Al Hadabi Jassim}

Master of Business Administration, Consultant of Murdoch University Business School, Dubai, United Arab Emirates (345005, Dubai, United Arab Emirates, Dubai International Academic City, Block 10); ORCID 0000-0003-3457-5737; e-mail: alhadabijassim@gmail.com.

\section{FOR CITATION}

Shershneva E. G., Bakr Hasan H. B., Al Hadabi J. Econometric Modeling of the Bank's Short-Term Liquidity Dynamics Based on Multi-Factor Regression. Journal of Applied Economic Research, 2020, Vol. 19, No. 1, 79-96. DOI: 10.15826/vestnik.2020.19.1.005

\section{ARTICLE INFO}

Received February 26, 2020; Revised March 12, 2020; Accepted March 16, 2020. 


\title{
Эконометрическое моделирование динамики краткосрочной ликвидности банка на основе многофакторной регрессии
}

\author{
Е. Г. Шеринева $\mathbb{D}^{\mathbb{D}} \bigotimes$, Х. Б. Бакр Хасан ${ }^{1} \mathbb{D}$, Д. Аль Хадаби ${ }^{2} \mathbb{D}$ \\ ${ }^{\prime}$ Уральский федеральный университет имени первого Президента России Б. Н. Ельцина, \\ г. Екатеринбург, Россия \\ ${ }^{2}$ Бизнес-школа Университета Мердока, \\ 2. Дубай, ОАЭ \\ \elena_sher@el.ru
}

\begin{abstract}
Аннотоция. В статье развиваются теоретико-методические аспекты предикативного анализа ликвидности в банковской сфере в контексте многообразия и компликации факторов, влияющих на ликвидную позицию современных банков. Целью работы является исследование зависимости краткосрочной ликвидности банка от ряда экономических показателей деятельности на основе эконометрического моделирования. При написании статьи применялся системный аналитический подход к изучению факторов формирования ликвидности, использовались приемы сравнительного анализа данных. Ключевым методическим инструментом эмпирической части исследования послужил многофакторный корреляционно-регрессионный анализ на основе параметрического выбора показателей деятельности крупного уральского банка. В рамках данного исследования не подтвержден доминирующий тезис о негативном влиянии избыточной ликвидности на уровень рентабельности коммерческих банков. Так, сравнительный анализ нормативов ликвидности и показателей рентабельности активов разномасштабных российских банков за период 2015-2019 гг. не выявил явной обратно-пропорциональной связи между ликвидностью и доходностью. Анализ парных корреляций также не обнаружил тесной зависимости между величиной норматива текущей ликвидности и операционной прибылью банка. Авторами отмечено, что небольшие по величине активов банки способны демонстрировать сочетание избыточной ликвидности и высокой доходности, в то время как более крупные банки могут не достигать таких результатов. Следовательно, масштаб деятельности банка не является определяющим фактором ликвидности, однако косвенно обеспечивает быстрый доступ к источникам фондирования. Научно-практическим результатом исследования выступают построенные авторами регрессионные модели зависимости обязательного норматива текущей ликвидности банка от ряда показателей деятельности, позволяющие осуществлять прогнозно-аналитическую оценку состояния ликвидности на краткосрочный период. Установлено, что на динамику ликвидности банка оказывают существенное влияние такие параметры, как собственный капитал, краткосрочные обязательства и просроченная ссудная задолженность. Предложенный подход может быть использован аналитическими службами коммерческих банков при разработке предикативных моделей мониторинга ликвидной позиции.
\end{abstract}

Ключевые слова: коммерческий банк; банковский сектор; ликвидность; факторы ликвидности; риск несбалансированной ликвидности; норматив текущей ликвидности; управление ликвидностью; капитал; краткосрочные обязательства; ликвидные активы. 


\section{Список использованных источников}

1. Кейнс Дж. М. Общая теория занятости, процента и денег. М.: Прогресс. 1978. 494 с.

2. Fisher D. Money and Banking. Homewook: Irwin.; 1971. 418 p.

3. Ривуар Ж. Техника банковского дела / пер. с фр. ; под общ. ред. И. В. Широких. М.: Прогресс-Универс. 1993. 157 с.

4. Berger A.N., Bouwman C.H.S. Bank Liquidity Creation, Monetary Policy, and Financial Crises // SSRN Electronic Journal. 2012. March. DOI: http://dx.doi.org/10.2139/ssrn.1952728.

5. Gertler M., Kiyotaki N. Banking, liquidity and bank runs in an infinite horizon economy // NBER Working Paper. 2013. No. 19129. 43 p.

6. Kashyap A. K., Rajan R. G., Stein J. C. Banks as liquidity providers: an explanation for the coexistence of lending and deposit-taking // Journal of Finance. 2002. Vol. 57, Issue 1. Pp. 33-73.

7. Логутова С.В. Ликвидность коммерческих банков: причины кризиса и управление риском // Вестник Новгородского государственного университета. 2011. № 61. С. 31-34.

8. Acharya V.V., Naqvi H. The Seeds of a Crisis: A Theory of Bank Liquidity and Risk-Taking Over the Business Cycle // NYU Working Paper. 2010. No. 2451/29886. 60 p.

9. Бурлачков В. К., Головнин М. Ю., Тихонов А. О. Глобальная денежная ликвидность: теоретические основы, показатели, тенденции динамики // Деньги и кредит. 2017. № 12. С. 3-8.

10. Van den End J. W. Liquidity stress-tester: a model for stress-testing banks liquidity risk // CESifo Economic Studies. 2010. Vol. 56, Issue 1. Pp. 38-69.

11. Adrian T., Shin H.S. Liquidity and financial contagion, in Banque de France // Financial Stability Review - Special Issue on Liquidity. 2008. Issue. 11. Pp. 1-7.

12. Goodhart C.A.E., Sunirand P., Tsomocos D. P. A model to analyze financial fragility // Economic Theory. 2006. Vol. 27, Issue 1. Pp. 107-142.

13. Dinger $V$. Do foreign-owned banks affect banking system liquidity risk? // Journal of Comparative Economics. 2009. Vol. 37, Issue 4. Pp. 647-657.

14. Шершнева Е.Г., Кондюкова Е. С., Полякова А. В. Влияние резервных требований Банка России на состояние банковской ликвидности и денежной массы // Финансы и кредит. 2017. Т. 23, № 27 (747). С. 1597-1613.

15. Ledrut E. Simulating retaliation in payment systems: can banks control their exposure to a failing participant? // DNB Working Paper. No. 133. Netherlands Central Bank, Research Department, 2007.

16. Eichengreen B., Gupta P. The financial crisis and Indian banks: survival of the fittest? // Journal of International Money and Finance. 2013. Vol. 39. Pp. 138-152.

17. Diamond D. W., Rajan R. G. Liquidity shortages and banking crises // Journal of Finance, American Finance Association. 2005. Vol. 60, Issue 2. Pp. 615-647.

18. Berger A. N., Bouwman C. H.S. Bank liquidity creation // Review of Financial Studies. 2009. Vol. 22. P. 3779-3837.

19. Horvath R., Seidler J., Weill L. Bank capital and liquidity creation: granger-causality evidence // Journal of Financial Services Research. 2014. Vol. 45, Issue 3. Pp. 341-361.

20. Bonfim D., Kim M. Liquidity risk in banking: is there herding? // European Banking Center Discussion Paper. 2012. No. 2012-024. DOI: https://doi.org/10.2139/ssrn.2163547.

21. Bonner C., Van Lelyveld I., Zymek R. Bank liquidity buffers and the role of liquidity regulation // Journal of Financial Services Research. 2015. Vol. 48, Issue 3. Pp. 215-234.

22. Moussa M.A.B. The determinants of bank liquidity: case of Tunisia // International Journal of Economics and Financial Issues. 2015. Vol. 5, Issue 1. Pp. 249-259.

23. Singh A., Sharma A.K. An empirical analysis of macroeconomic and bank-specific factors affecting liquidity of Indian banks // Future Business Journal. 2016. Vol. 2. Pp. 40-53.

24. Aspachs $O$., Nier E., Tiesset $M$. Liquidity, banking regulation and the macroeconomy. Evidence on bank liquidity holdings from a panel of UK-resident banks // Bank of England Working Paper. 2005. 26 p. 
25. Vodová $P$. Determinants of commercial bank liquidity in Hungary // Finansowy Kwartalnik Internetowy e-Finanse. 2013. Vol. 9, Issue 4. Pp. 64-71.

26. Lartey V. C., Antwi S., Boadi E. K. The relationship between liquidity and profitability of listed banks in Ghana // International Journal of Business and Social Science. 2013. Vol. 4, Issue 3. Pp. 48-56.

\section{ІИНФОРМАЦИЯ ОБ АВТОРАХ}

\section{Шершнева Елена Геннадьевна}

Кандидат экономических наук, доцент кафедры банковского и инвестиционного менеджмента Уральского федерального университета имени первого Президента России Б. Н. Ельцина, г. Екатеринбург, Россия (620002, г. Екатеринбург, ул. Мира, 19); ORCID 0000-0002-6739-8960; e-mail: elena_sher@el.ru.

\section{Хасан Бархам Бакр Хасан}

Магистрант кафедры банковского и инвестиционного менеджмента Уральского федерального университета имени первого Президента России Б. Н. Ельцина, г. Екатеринбург, Россия (620002, г. Екатеринбург, ул. Мира, 19); ORCID 0000-0002-5239-4537; e-mail: barhambakr@gmail.com.

\section{Джассим Аль Хадаби}

Master of Business Administration, консультант Бизнес-школы Университета Мердока, г. Дубай, Объединенные Арабские Эмираты (345005, Dubai, United Arab Emirates, Dubai International Academic City, Block 10); ORCID 0000-0003-3457-5737; e-mail: alhadabijassim@gmail.com.

\section{ДЛЯ ЦИТИРОВАНИЯ}

Шершнева Е. Г., Бакр Хасан Х.Б., Аль Хадаби Д. Эконометрическое моделирование динамики краткосрочной ликвидности банка на основе многофакторной регрессии // Journal of Applied Economic Research. 2020. T. 19, № 1. C. 79-96. DOI: 10.15826/vestnik.2020.19.1.005.

\section{ИНФОРМАЦИЯ О СТАТЬЕ}

Дата поступления 26 февраля 2020 г.; дата поступления после рецензирования 12 марта 2020 г.; дата принятия к печати 16 марта 2020 г. 